\author{
Magda Nabiałek \\ Wydział Polonistyki \\ Uniwersytet Warszawski \\ e-mail: magdanabialek@uw.edu.pl \\ ORCID: 0000-0003-2487-5146
}

\title{
Afekt i konwencja - budowanie przestrzeni widzenia
}

Badania nad afektywnością literatury skupiają się $\mathrm{w}$ dużej mierze na analizie stanów emocjonalnych utrwalonych $\mathrm{w}$ dziele sztuki ${ }^{1}$. Rozważania tego typu siłą rzeczy koncentrują się więc na badaniu literatury XX i XXI stanowiącej w dużej mierze zapis przeżyć i doświadczeń jednostki lub grup społecznych związanych m.in. z Holocaustem, które odciskają niezatarte piętno na kształcie twórczości, nie tylko zresztą literackiej. Co jednak z twórczością wcześniejszą, do której badacze afektywności zdają się sięgać dużo rzadziej?

Rebecca Schneider w swoim studium Performing Remains podjęła dość istotne zagadnienie współistnienia performansu i archiwum. Badaczka, podążając za dotychczasowymi rozpoznaniami, podkreślającymi opozycyjność tych dwóch fundamentalnych dla kultury Zachodu XX wieku pojęć, zwraca uwagę na to, że "tylko to, co może być rozpoznane jako resztka, co może zostać udokumentowane lub stać się dokumentem, ma zapewnione miejsce w archiwum" 2 . "Resztki”, które znajdują się w naszym kulturowym archi-

\footnotetext{
1 R. Braidotti, Afirmation, Pain and Empowerment, "Asian Journal of Women Studies" 2018, Vol. 14, No 3; B. Massumi, Autonomia afektu, przeł. A. Lipszyc, „Teksty Drugie” 2013, nr 6; E. Kosofsky Sedgwick, Touching Feeling. Affect, Pedagogy, Performativity, Durham - London 2003.

2 R. Schneider, Performing Remains. Art and War in Times of Theatrical Reenactment, London-New York 2013, s. 23.
} 
wum, okazują się jednak mieć ogromną siłę oddziaływania. To właśnie owe „resztki” mogą posłużyć dziełu literackiemu do budowania afektywnej więzi $\mathrm{z}$ odbiorcą $\mathrm{w}$ performansie (jeśli trzymać się terminologii przyjętej przez Schneider) lub szerzej - różnego rodzaju utworach dramatycznych (najczęściej pisanych jednak z myślą o wystawieniu).

Jeśli uznać performans za sposób podtrzymania żywej pamięci ${ }^{3}$, niejednokrotnie związany z praktykami obnażania hegemonii wzroku, ale i budowania afektywnej relacji $z$ odbiorcami, uznać trzeba, że występowanie tego zjawiska nie ogranicza się do XX wieku. Godnym uwagi poprzednikiem dzisiejszych praktyk performatywnych (zgodnie z myśleniem Schneider opierających się na akcie pozostawiania, przywoływania, ponownego pojawienia się i uczestnictwa), są utwory teatralne z przełomu XIX i XX wieku. Tak często krytykowana konwencjonalność tych dzieł, analizowana jako narzędzie wywołujące u czytelników/widzów określonego typu afekty i służąca do budowania określonego modelu odbioru kreowanej na scenie rzeczywistości, nabiera zupełnie innego charakteru. Okazuje się bowiem, że tylko z pozoru afekt i konwencja to zjawiska się wykluczające. Afekt opiera się przecież $\mathrm{w}$ dużej mierze właśnie na sile pamięci, a formą, w której zostaje ona utrwalona, może być m.in. konwencja. Wydaje się, że to właśnie twórcy z II połowy XIX wieku i początku wieku XX w absolutnie zaskakujący sposób nauczyli się wykorzystywać potencjał tkwiący w konwencjach teatralnych.

Charakterystyczne dla sztuki tego okresu dążenie do przywrócenia scenom teatralnym komedii dell'arte, związanej z nią improwizacji, dramy czarodziejskiej, szopki i wielu podobnych im form dramatycznych nie jest jedynie, jak chciałaby część badaczy, wyrazem tęsknoty za zapominaną tradycją literacką. Warto bowiem zwrócić uwagę, że wszystkie przywołane tutaj formy wyróżnia "nażywość" ${ }^{4}$. Zasadnym więc zdaje się twierdzenie, że szczególnie na przełomie XIX i XX wieku mamy do czynienia $\mathrm{z}$ renesansem silnie utrwalonych w tradycji konwencji dramatycznych, które mają w sobie jednak bardzo duży potencjał do budowania afektywnej relacji z odbiorcą właśnie poprzez ową ukrytą w ich formie "nażywość".

W związku z ograniczoną formą tego artykułu zdecydowałam się na wskazanie trzech, najbardziej moim zdaniem wyrazistych form dramatyczno-teatralnych, czyli odrodzonej w połowie XIX wieku we Włoszech komedii

3 Tamże, s. 27. W przeciwieństwie do archiwum, które traktuje się jako tryb działania władzy wymierzony przeciwko pamięci. Zob. A.L. Stoller, Colonial archives and the arts of governance, "Archival Science" 2002, No 2.

4 M. Sugiera, Nażywość, w: Performatyka. Terytoria, red. E. Bal, D. Kosiński, Kraków 2017. 
dell'arte, rosyjskiego bałaganu, z którego czerpał zarówno rosyjski symbolizm, jak i awangarda, a także polskiej baśni dramatycznej, której badacze dotychczas nie poświęcili wiele miejsca. Oczywiście w tym kontekście należałoby wspomnieć także o tradycji szopki, kabaretu, o związku dramatu i teatru z kulturą cyrku. Związki wszystkich tych form $\mathrm{z}$ afektywną mocą konwencji to jednak temat na osobną rozprawę.

Wskazane przeze mnie trzy formy dramatyczne stanowią jednak w pewnym sensie archiwum afektywnej, zbiorowej, kolektywnej pamięci kulturowej. Składają się na nią utwory zbudowane ze znanych i rozpoznawalnych przez XIX- i XX-wieczną widownię kulturowych scenariuszy. Jednocześnie zaś każda z tych form nawiązuje do sztuki „na żywo". Wydaje się, że to właśnie w połączeniu tych dwóch elementów - konwencjonalności i „nażywości" - kryje się siła afektywnego oddziaływania tych sztuk na współczesną im widownię.

\section{Komedia dell'arte - „nażywość” i lokalność}

Komedia dell'arte to znak rozpoznawczy włoskiej sztuki teatralnej. Po okresie ogromnego rozkwitu w XVI i XVII wieku została ona jednak stopniowo zepchnięta na margines. Zamiast niej zaczęto w największych włoskich teatrach grać sztuki klasyczne, przeróbki dramatów francuskich, a sama komedia dell'arte przesunięta została w stronę teatru dialektalnego, który wielu intelektualistów bardzo silnie atakowało, postrzegając go jako wyraz plebejskości i nieprzyzwoitości lokalnej sztuki. To właśnie jednak w teatrze lokalnym komedia dell'arte znalazła schronienie. Jej kontynuację stanowi jednak teatr all'antica italiana oraz capocomico. Był to teatr lokalny, który wyraźnie jednak opierał się obcym wzorcom. Konwencja sięgająca do tradycji komedii dell'arte okazała się tutaj formą obrony przed tym co obce, sztucznie przeniesione z innej kultury i nieprzystające do potrzeb ówczesnej publiczności.

Siła afektu uruchomionego przez konwencjonalność sztuk powstających w II połowie XIX wieku była ogromna. Świadczy o tym choćby popularność sztuk Antonia Petito ${ }^{5}$, który przerabiał dramaty mieszczańskie, klasyczne, promowane przez ówczesną włoską arystokrację oraz mieszczaństwo, właśnie z wykorzystaniem kanw i kulturowych scenariuszy tak dobrze znanych

\footnotetext{
5 Wywodził się z rodziny prowadzącej lokalny teatr. Przez wiele lat jego ojciec nosił maskę Pulcinelli, którą przejął później jego syn, podobnie jak kierowanie teatrem San Carlino. Petito zmarł na scenie w 1876 roku podczas spektaklu Donna bianca.
} 
włoskiemu społeczeństwu z komedii dell'arte. Najlepszym przykładem takiej strategii jest jego przeróbka Franceski da Rimini (1860) ${ }^{6}$, w której to w roli tytułowej bohaterki obsadził on włoskiego Pulcinellę. Ten pierwszy gest uruchomił całą lawinę rozwiązań fabularnych, które sprawiły, że stworzony w sztuce świat balansował na granicy utożsamienia się bohaterów z rolą i wychodzenia $\mathrm{z}$ niej ${ }^{7}$. Petito na swój sposób oswoił kulturowy kanon. Jego sztuki to przede wszystkim twórczość rozrywkowa, przyciągająca do prowincjonalnego teatru spragnionych emocji widzów. O ile Franceskę można uznać jeszcze za parodię, o tyle późniejszy Don Faust (1865) bardzo bliski jest już formie pastiszu. Wykorzystanie zepchniętej na boczny tor literatury improwizacyjnej tradycji teatralnej pozwoliło obnażyć nieprzystawalność obcego wzorca kulturowego do warunków lokalnej twórczości. Niepotrzebny był tutaj rezonerski głos autora, ponieważ wykorzystywane w sztuce konwencje były na tyle wyraziste i uruchamiały w pamięci widzów gotowe, doskonale im znane scenariusze.

Konfrontacja obcej sztuki z rozwiązaniami narzuconymi jej przez określoną praktykę sceniczną, jakiej znakiem były konwencje zaczerpnięte z komedii dell'arte, pozwalała na projektowanie określonej relacji z publicznością. Dramat okazał się nie tylko tworzeniem konstrukcji słownych uruchamiających określone zespoły przedstawień, lecz także formą kształtowania pewnej rzeczywistości teatralnej ${ }^{8}$ i prowokowania afektywnej reakcji ze strony publiczności.

W latach 30. XX wieku bardzo podobny sposób budowania rzeczywistości teatralnej zaprezentuje między innymi współpracownik Luigiego Pirandello, a później samodzielny twórca - Eduardo de Filippo, który korzystając z tradycji ludowej rozrywki, jeszcze silniej niż Petito (a także autor Sześciu postaci scenicznych w poszukiwaniu autora) będzie balansował na granicy serio i buffo. Wiele rozwiązań formalno-tekstowych będzie przypominało te, którymi jeszcze w XIX wieku posługiwał się twórca teatru San Carlino. Bardzo wyrazistym przykładem tego sposobu projektowania rzeczywistości dramatycznej jest utwór Natale in casa Cupiello (1931-1934), który

\footnotetext{
6 Sztuka powstała na podstawie tragedii Silvio Pellico, Fracesca da Rimini, z 1815 roku.

7 Zmiany te zaznaczone zostały także $\mathrm{w}$ strukturze wersyfikacyjnej utworu: rozpadała się ona na metaforyczne, bardzo rozbudowane pod względem stylistycznym fragmenty zapisane trzynastozgłoskowcem oraz krótkie, wyraziste, niejednokrotnie kolokwialne wypowiedzi w postaci ośmiozgłoskowca.

8 Podejście to omawiał Juliusz Kleiner w swoim artykule Istota utworu dramatycznego. Zob. J. Kleiner, Istota utworu dramatycznego, „Listy z Teatru” 1948, nr 24. Przedruk w: tegoż, Studia z zakresu teorii literatury, Lublin 1956.
} 
wykorzystuje motyw szopki bożonarodzeniowej (notabene niezwykle popularny również w Polsce lat 20. i 30.). Konwencjonalna nie jest tutaj jednak akcja nawiązująca do narodzin Chrystusa, lecz sytuacja rodziny głównego bohatera, który zajmuje się sklejaniem szopki z różnego rodzaju odpadków gromadzonych skrupulatnie przez cały rok i nie widzi rozgrywającego się obok niego, ponieważ "konwencjonalnego" dramatu: syn dopuszcza się kradzieży, małżeństwo córki przeżywa kryzys, żona natomiast udaje, że wszystko jest w najlepszym porządku. Teoretycznie można by więc uznać, że jest to typowy dramat mieszczański, przypominający momentami bardziej modernistyczny dramat wnętrza. Taką kwalifikację uniemożliwiają jednak różnego rodzaju tricki, za pomocą których wprowadzane na scenę są kolejne stereotypowe postaci. Nie brakuje tutaj wodewilowych qui pro quo, teatralnych coup de théâtre oraz kabaretowych skeczów. Dzięki nim ujawnia się cała seria konfliktów między bohaterami. Najbardziej zaskakujące jest jednak wykorzystanie tradycyjnego błogosławieństwa, którego główny bohater udziela pozostałym członkom rodziny na łożu śmierci, sankcjonując tym samym całkowicie odwrócony porządek społeczny. W wyniku tego (jakże zresztą teatralnego) gestu powstaje nowy model dramatu, który garściami czerpie z komedii dell'arte, tradycyjnego teatru dialektalnego. Kanwy, scenariusze teatralne, zakorzenione we włoskiej tradycji teatralnej postaci pomagają twórcy budować afektywną relację z publicznością, która była warunkiem utrzymania świata zawieszonego między prawdą i pozorem, życiem i grą.

\section{Rosyjski bałagan i teatr Pietruszki}

Wskazanie tradycji teatralnej, której odnowienie postulowaliby twórcy tacy jak Aleksandr Błok, później Nikołaj Jewrieinow czy Jurij Wachtanow jest znacznie trudniejszym zadaniem. Rosjanie mieli oczywiście swoją tradycję twórczości ludowej, natomiast w XIX wieku połączyła się ona w nierozerwalny węzeł z wpływami komedii dell'arte. Warto bowiem przypomnieć, że wygnani z Italii komicy zawędrowali z czasem także do carskiej Rosji, gdzie ich sztuka spotkała się z bardzo dużym zainteresowaniem9. Jej improwizacyjny charakter stawiał ją obok innych „nażywych” form takich jak cyrk, kult clowna (ryzhii) czy teatru ulicznego. Ten ostatni, czyli

\footnotetext{
9 Więcej o "transferach kulturowych" związanych z komedią dell'arte zob. w: Teatr dell'arte, red. D. Sosnowska, Warszawa 2016 oraz E. Bal, Lokalność i mobilność kulturowa teatru. Śladami Arlekina i Pulcinelli, Kraków 2017.
} 
rosyjski bałagan przejął bardzo wiele elementów włoskiej sztuki teatralnej $\mathrm{i} \mathrm{w}$ ten sposób powstał słynny teatr Pietruszki ${ }^{10}$. Jednocześnie obok jarmarcznej budy, komedii dell'arte ${ }^{11}$ coraz silniej obecnej w twórczości autorów szukających drogi do odnowienia rosyjskiego dramatu i teatru pojawiało się misterium ${ }^{12}$ (połączeniem tych ludowych i religijnych form teatralnych będzie np. Misterium buffo Włodzimierza Majakowskiego z 1918 roku). Oprócz najczęściej przywoływanego w tym kontekście utworu A. Błoka (Buda jarmarczna), warto wskazać na dramat Władimira Sołowiewa (Arlekin swatem, 1911) oraz utwory Leonida Andriejewa (Czarne maski, 1908 i Ten, którego bija po twarzy, 1915).

Przyglądając się dramatom zarówno z pierwszego dziesięciolecia XX wieku, jak i okresu nieco późniejszego, nie sposób nie zwrócić uwagi na zastanawiającą (szczególnie w przypadku autorów deklaratywnie poszukujących nowych form wyrazu) konwencjonalność wykorzystanych przez nich form dramatycznych. Warto jednak podkreślić jednocześnie charakterystyczną dla tych utworów rywalizację między konkurencyjnymi konwencjami, formami i wyrastającymi z nich stylami wypowiedzi, która dokonuje się w obrębie jednego utworu. To wzajemne nicowanie się konwencji, doskonale znanych przecież ówczesnej publiczności, gwarantuje nawiązanie z nią afektywnej, niejednokrotnie bardzo gwałtownej relacji. Konwencje mają bowiem na celu uruchomienie afektywnej pamięci widzów, przywołanie określonych, zepchniętych z czasem do kulturowego archiwum wzorców i formuł teatralnych oraz - co najważniejsze - związanych z nimi sposobów koncep-

10 Szczegółowe omówienie tego zjawiska znaleźć można w monografii: J.D. Clayton, Pierrot in Petrograd. The Commedia dell'Arte/Balagan in Twentieth-Century Russian Theatre and Drama, Montreal-Kingstion-London-Buffalo 1993; C. Kelly, Petrushka: The Russian Carnival Puppet Theatre, Cambridge 2009.

11 Już Lo Gatto podkreślał związki łączące włoskie arlekinady z rdzennie rosyjską formą budy jarmarcznej. Zetknięcie to mogło nastąpić już w XVIII wieku, kiedy pierwsze trupy włoskie zawędrowały do Rosji. W 1733 r. do Petersburga przybyła trupa Tommasa Ristoriego. Mniej więcej w tym samym czasie w Rosji pojawił się jeszcze jeden słynny Arlekin, czyli Antonio Vulcano. W XVIII wieku powstał także pokaźny zestaw scenariuszy opartych na formule komedii dell'arte napisanych w języku rosyjskim. Zob. E. Lo Gatto, La Commedia dell'arte in Russia, „Rivista di studi teatrali" 1954, nr 9-10.

12 Nie można zapominać, że arlekinada rozumiana jako maskarada łączy się nie tylko z tradycją XVI-wiecznej włoskiej komedii dell'arte, lecz także ze światem misteriów dionizyjskich, jak również średniowiecznym i nowożytnym obrzędem maskaradowym, w tym z tzw. „świętem wiosny" noszącym znamiona ludowej maskarady. Warto przypomnieć, że tym ostatnim korowodom u ludów archaicznych przewodził najpierw szaman w masce, potem satyr, w średniowieczu zaś diabeł. Na szatana jako protoplastę postaci Arlekina wskazywał również A. Wiesiołowski Alichino e Aredolesa, "Giornale storico della Letteratura italiana" 1898, XI. 
tualizacji świata ${ }^{13}$. To konwencja uruchamiająca afektywną relację z odbiorcą służy twórcom do przekształcania zastanego przez nich pola produkcji literackiej, mówiąc językiem Pierre'a Bourdieu. Komedia dell'arte, jej twórcze przekształcenie $\mathrm{w}$ postaci teatru Pietruszki i rosyjskiego bałaganu, staje się jednym z ważniejszych narzędzi przemiany sztuki rosyjskiej na początku XX wieku (Catriona Kelly twierdzić wręcz będzie, że pojawienie się komedii dell'arte $\mathrm{w}$ Rosji traktować także należy jako zjawisko z porządku socjologicznego $\left.^{14}\right)$.

Sztukę włoską z II połowy XIX wieku i tę powstającą na początku nowego wieku w Rosji łączyć zdają się podstawowe założenia programowe. Zdaniem Johna Douglasa Claytona to między innymi tradycja komedii dell'arte umożliwiała odnowienie relacji między teatrem a publicznością, aktorem a widownią ${ }^{15}$. „Nażywość”, improwizacja, sięganie do twórczości rozrywkowej - wszystkie te cechy ówczesnej produkcji dramatycznej wyraźnie świadczą o potrzebie budowy relacji z odbiorcą na nowych zupełnie zasadach. Konwencja nie służy już do konceptualizacji świata przedstawionego, wyraźnego zaznaczenia ram jego funkcjonowania, a przez to opisania i wytłumaczenia rzeczywistości otaczającej widzów. Przywołanie określonych konwencji, doprowadzenie do ich starcia, ma wzbudzać emocje, ma przekształcać sposób widzenia świata przez widza bez dawania mu gotowych odpowiedzi na dręczące go pytania. Odtwarzano więc ów uliczny teatr włoski w najczystszej możliwej formie, posługiwano się jedynie scenariuszem (kanwą) i sztuką improwizacji. W twórczości Błoka czy Jewrieinowa pełno postaci zamkniętych $\mathrm{w}$ serii karykaturalnych gestów i zdarzeń, nowoczesnych odpowiedników XVI- i XVII-wiecznych lazzi, bohaterów prezentujących groteskowy obraz siebie i otaczającego ich świata. Wszystko to służyło przywołaniu pamięci widzów, uruchomieniu określonych afektów i przeformułowaniu wizji świata dramatycznego.

Najbardziej wyrazistym przykładem wprowadzenia tego typu rozwiązań do sztuki przełomu XIX i XX wieku jest oczywiście Buda jarmarczna Błoka. Przestrzeń dramatu zbudowana jest z dwóch, konwencjonalnych, do-

13 Wydaje się, że nie bez powodu Meyerhold w swoim programie nauczania uwzględniał wiedzę m.in. o teatrze komedii dell'arte, o czym przypomina Katarzyna Osińska w swojej pracy Teatr rosyjski XX wieku wobec tradycji: kontynuacje, zerwania, transformacje, Gdańsk 2009.

14 C. Kelly, Petrushka: The Russian Carnival Puppet Theatre.

15 „The goal of the theatrical revolution signified by the insertion of the commedia dell'arte element into the theatrical performance was a new theatre that would provoke and challenge both actor and audience, and force both to see afresh the nature of the relationship between them that is the essence of the theatrical experience" [J. D. Clayton, Pierrot in Petrograd. The Commedia dell'Arte/Balagan in Twentieth-Century Russian Theatre and Drama, s. 6]. 
skonale utrwalonych $\mathrm{w}$ tradycji teatralnej miejsc. Jednym jest typowy "pokój teatralny z trzema ścianami, oknem i drzwiami" (znak, a właściwie karykatura tradycyjnego, skompromitowanego już w tym okresie XIX-wiecznego dramatu), drugi z kolei stanowi przestrzeń ludowego bałaganu (rosyjski Балаган był symbolem tradycyjnego teatru ludowego, związanego ściśle $\mathrm{z}$ improwizacją) ${ }^{16}$. Odsłonięcie kulis pozwala na zastąpienie pierwszej, sztucznej przestrzeni, przestrzenią zamieszkaną m.in. przez Pierrota, Kolombinę i Arlekina. Przestrzeń wprost komunikująca swoją sztuczność, karykaturalność, szablonowość okazuje się być bardziej „rzeczywista” od świata, w którym Trzej Mistycy oczekują nadejścia Bladej Przyjaciółki. Te dwie konwencje - improwizacyjna oraz realistyczno-mistyczna podważają się jednak nawzajem. „Teatr w teatrze” Błoka nie działa tak, jak można byłoby się tego spodziewać. Nie wyróżnia go prosta budowa szkatułkowa, ale konstrukcja sygnalizująca potrzebę stworzenia prawdziwego świata teatru, który możliwy jest tylko dzięki aktywnemu uczestnictwu publiczności. Warunkiem podjęcia przez publiczność owej wyznaczonej jej przez artystę roli jest afekt, którego regulatorem okazuje się konwencja uruchamiająca pamięć kulturową.

W dramacie rosyjskim Srebrnego Wieku doszło jednak do szczególnego zjawiska - narzędziem odnowy teatru stała się forma z jednej strony stricte artystyczna (czyli XVI-wieczna komedia dell'arte), z drugiej - forma najbardziej ludowa i pierwotna dla rosyjskiego teatru, czyli rosyjski bałagan, jednocześnie nierozerwalnie $\mathrm{z}$ tą pierwszą związany. Plac, tak bardzo charakterystyczny dla rosyjskiego teatru ludowego, stanie się podstawowym miejscem akcji dramatów twórców takich, jak Jewrieinow i Tairow ${ }^{17}$. To uruchomienie afektywnej pamięci o rodzimej tradycji ludowej będzie ogromnie istotne także podczas „reformatorskich” (przede wszystkim jednak na polu społeczno-politycznym, aniżeli teatralnym) działań Włodzimierza Majakowskiego. Warto zwrócić uwagę na charakterystyczny splot tradycji formy

\footnotetext{
16 Historia rosyjskiego bałaganu i jego związki z ludowym rosyjskim teatrem zasługują na szersze omówienie. Pierwszych ważnych rozpoznań dokonał w tym zakresie przede wszystkim John Douglas Clayton, który powiązał tradycję teatru Pietruszki z obecnością w Rosji wędrownych teatrów włoskich. Co ważne, obecność tradycji ludowej w dramaturgii rosyjskiej przełomu XIX i XX wieku dostrzegano nie tylko w twórczości Błoka. M.in. Helena Kotow zwracała uwagę, że: „Dramaturgia Fiodora Sołoguba jest jakby rosyjską wersją realizacji głoszonego na zachodzie Europy hasła teatralizacji teatru umowności, stylizacji scenicznej, reinterpretacji mitów greckich, średniowiecznych legend i podań ludowych" [H. Kotow, Tradycje teatru ludowo-jarmarcznego w dramacie Fiodora Sołoguba "Wańka klucznik i jego paź Jean", "Zeszyty Naukowe Wydziału Humanistycznego Uniwersytetu Gdańskiego. Filologia Rosyjska", 1982, t. 10, s. 35].

17 Zob. Tairow, Notatki reżysera i proklamacje artysty, przeł. J. Ludawska, Warszawa 1978.
} 
buffo, komedii dell'arte, improwizacji i tradycji misterium, jaki ma miejsce w Misterium buffo. Pozorną sprzeczność tych dwóch gatunków (tak przecież konwencjonalnych) łączy "nażywość” obydwu form ${ }^{18}$. Siła afektu rodzi się właśnie z połączenia „nażywości” i konwencjonalności. Rosjanie zdawali się to na początku XX wieku rozumieć lepiej niż ktokolwiek inny. Być może dlatego osiągnięcia Wielkiej Reformy Teatralnej we Francji, w tym koncepcja wielkiej marionety Craiga nie spotkała się z tak dużym zainteresowaniem $\mathrm{z}$ ich strony.

\section{Baśń dramatyczna a rozwój polskiego dramatu}

Baśń dramatyczna pozostaje formą (uznanie jej bowiem za gatunek jako taki budzić może bowiem spore wątpliwości) słabo obecną zarówno w badaniach dramatologicznych, jak i teatralnych, choć w przypadku tych drugich więcej uwagi poświęca się zjawiskom kontekstowym dla baśni dramatycznej, czyli wystawianym namiętnie w XIX wieku w Polsce dramom czarodziejskim, kasperliadom i podobnym im utworom ${ }^{19}$. Nic więc dziwnego, że próba ustalenia genologicznego charakteru baśni dramatycznej z góry właściwie skazana jest na porażkę, na co zwracali uwage jedyni do tej pory zajmujący się bliżej tą formą badacze - Ryszard Waksmund ${ }^{20}$ i Anna Czabanowska-Wróbel ${ }^{21}$ (choć trzeba zaznaczyć, że robili to raczej przy okazji innych, szerzej zakrojonych badań). Niemniej przypomnieć trzeba, że baśń dramatyczna była formą bardzo popularną w okresie Młodej Polski. Sięgali po nią zapomniani dzisiaj twórcy tacy jak Zygmunt Sarnecki, Aleksander Niemojewski, Artur Oppman, ale i ci, którzy w historii literatury polskiej zapisali się na stałe - Lucjan Rydel, Leopold Staff czy Bolesław Leśmian. Poszczególni twórcy opatrywali swoje dzieła bardzo różnymi podtytułami: powieść sceniczna, fantazja, poemat dramatyczny, baśń, baśń sceniczna, baśń mimiczna. W okresie 1890-1918 powstało bardzo wiele utwo-

\footnotetext{
18 Mimo utrwalonego powszechnie przekonania o szablonowości i hermetyczności formy misterium, warto podkreślić bezpośredniość akcji tego typu utworów, nawiązywanie relacji $\mathrm{z}$ widownią, dostosowywanie się do lokalnych warunków, w których dochodziło do przedstawienia. Na wszystkie te elementy w odniesieniu do najstarszych zachowanych utworów angielskich zwracał uwagę Mirosław Kocur w swojej pracy Teatr bez teatru.

19 Zob. E. Nowicka, Omamienie - cudowność - afekt. Dramat w kręgu dziewiętnastowiecznych wyobrażeń i pojęć, Poznań 2003.

20 R. Waksmund, Młodopolska baśn dramatyczna. Od bajki ludowej do impresji scenicznej (z zagadnień struktury gatunku), w: Baśnie nasze wspótczesne, red. J. Ługowska, Wrocław 2005.

21 A. Czabanowska-Wróbel, Baśń w literaturze Młodej Polski, Kraków 1996.
} 
rów dramatycznych, które można byłoby zakwalifikować jako baśnie dramatyczne, większość ich jednak doczekała się wyłącznie jednego wydania, a następnie zniknęła zupełnie ze świadomości odbiorców literatury, nie ma również sensu szukać informacji o nich w kompendiach poświęconych literaturze tego okresu.

Dlaczego więc dzisiaj warto zajmować się baśnią dramatyczną? Skłania do tego przede wszystkim spojrzenie na nią z perspektywy nieco późniejszych dokonań w dramaturgii polskiej i eksperymentów, które pojawiły się $\mathrm{w}$ dwudziestoleciu międzywojennym. Zastanawiająca jest siatka przedstawieniowa baśni dramatycznej stworzona z połączenia komedii dell'arte, kasperliad, baśni czarodziejskich oraz contes de fées. Tej siatki przecinających się niejednokrotnie linii transferów kulturowych, inspiracji i konwergencji nie sposób wytłumaczyć niearcydzielnością większości przywoływanych w kontekście baśni dramatycznej utworów i charakterystycznym dla nich wynajdywaniem zapomnianych tradycji. Pytanie o baśn dramatyczną to pytanie o przepływ, sposób osadzenia elementów poszczególnych tradycji teatralnych na polskim gruncie kulturowym, a przede wszystkim pytanie o celowość tego zabiegu.

Bliższa analiza utworów określanych mianem baśni dramatycznej każe dostrzec związki łączące je z utworami Ewy Szelburg-Zarębiny (Ecco homo, Syngały), Witolda Wandurskiego (Śmierć na gruszy) czy Józefa Jaremy (Lajkonik w szopce). Dramaty dwudziestolecia międzywojennego bazowały na bardzo silnej, afektywnej relacji z odbiorcą (czemu sprzyjał zarówno klimat kabaretu, w którym osadzony były Crictot $\mathrm{I}^{22}$ czy rodzący się w Łodzi teatr proletariacki Wandurskiego ${ }^{23}$ ). Żeby jednak zrozumieć, z czego brała się owa szczególna siła (dla ówczesnej publiczności, przyznać bowiem trzeba, że wszystkie wymienione przeze mnie utwory są obecnie mało znane) tych tekstów i realizowanych na ich podstawie przedstawień, trzeba sięgnąć właśnie do tradycji baśni dramatycznej, która wyróżniała się na tle innych podobnych jej utworów szczególnym połączeniem baśniowości z misterium (oczywiście nie we wszystkich przypadkach, natomiast jest to rys silnie obecny w Skrzypku opętanym Bolesława Leśmiana, Arfie Macieja Szukiewicza, Zaczarowanym kole Lucjana Rydla).

22 Zob. K. Czerska, Teatr Cricot - suma przybliżeń, „Didaskalia” 2019, nr 153; J. Mazur-Fedak, Józef Jarema w międzywojennym teatrze awangardowym Cricot (I), Kraków 2008.

${ }^{23}$ Zob. L. Dorak-Wojakowska, Dramaturg jako archiwista. O stylu montażu dokumentalnego Witolda Wandurskiego i sceny robotniczej, „Annales Universitatis Paedagogicae Cracoviensis. Studia de Cultura" 2019, nr 2. 
Na te dwie linie rozwoju dramatu polskiego przełomu XIX i XX wieku bardzo wyraźnie zwracała uwagę Ewa Rzewuska ${ }^{24}$, wielokrotnie próbując jednak rozdzielić misterium/moralitet i baśń lub traktując tę drugą jako dodatkowy rys charakterystyczny dla niektórych utworów zanurzonych w kontekście religijnym. Wydaje się jednak, że w przypadku polskiej baśni dramatycznej, dla której oczywisty wręcz kontekst stanowi komedia dell'arte Carla Gozziego, Sen nocy letniej Williama Szekspira, niemieckie Zauberpose, kasperliady Franza Pozziego, contes de fées, satyry Ludwicka Tiecka czy Balladyna Juliusza Słowackiego, neoromantyczne baśni sceniczne Gerharta Hauptmanna i Maurice'a Maeterlincka, mówić trzeba o silnym misteryjno-baśniowym splocie, który jeszcze w pierwszym dziesięcioleciu XX wieku pozwala uzyskać możliwe spójny świat przedstawiony. W drugim i trzecim dziesięcioleciu dwa elementy tego rizomatycznego projektu zaczną się jednak wzajemnie nicować.

Baśń dramatyczną można więc w tym momencie postrzegać jako zapowiedź oryginalnych dramatów dwudziestolecia, które pełnymi garściami czerpać będą z cyrku, szopki, kabaretu i misterium. Baśń dramatyczna natomiast jako produkt określonego momentu historycznego (utwory te powstawały właściwie jedynie w okresie 1890-1918), tworzy przestrzeń, w której dochodzi do niezwykle interesującego połączenia wątków, motywów, fabuł, rozwiązań strukturalnych z zupełnie odmiennych rejestrów literatury. Korzystając z bogatego repertuaru kulturowych scenariuszy ${ }^{25}$, uruchamia afektywną pamięć (mimo trudnego często do zidentyfikowania archiwum ${ }^{26}$ ) swoich odbiorców, jednocześnie doprowadzając do modyfikacji, przekształcenia i twórczego przekroczenia określonych wzorców dramaturgicznych. Stąd też wielokrotnie pojawiające się zarzuty dotyczące niespójności świata tych utworów, mimo widocznego dążenia twórców do zamknięcia rzeczywistości w określonych ramach. Trudno Niemojewskiego, Sarneckiego, Oppmana czy nawet Rydla postrzegać jako wielkich reformatorów polskiego dramatu. Wydaje się jednak, że zainicjowane przez nich eksperymenty stanowiły cenne źródło inspiracji dla następców w postaci Szelburg-Zarębiny,

24 Polski dramat ekspresjonistyczny wobec konwencji gatunkowych, Lublin 1988; E. Rzewuska, Misterium $i$ moralitet $w$ polskim dramacie międzywojennym, w: Dramat $i$ teatr religijny $w$ Polsce, red. I. Sławińska, W. Kaczmarek, Lublin 1991, s. 287-328.

25 Pojęciem tym posługuję się za Dianą Taylor. Por. D. Taylor, The Archive and the Repertoire, Durham-London 2003. Fragment książki został przetłumaczony na język polski: D. Taylor, Archiwum i repertuar: performanse i performatywność. PerFORwhat studies?, przeł. M. Borowski, M. Sugiera, „Didaskalia” 2014, nr 120.

${ }^{26}$ Pojęciem archiwum posługuję się również za Dianą Taylor. Zob. D. Taylor, The Archive and the Repertoire. 
Wandurskiego, Zegadłowicza czy Jaremy. Szczególnie ten ostatni miał, jak sądzę, świadomość afektu ukrytego w wykorzystywanych przez niego konwencjach. Zresztą w kręgu Criocot nie był raczej w tym myśleniu osamotniony. Wystarczy przypomnieć, że oprócz Jaremy jedną z ważniejszych postaci teatru na Łobzowskiej w Krakowie był Adam Polewka, autor Igrców na barbakanie i tłumacz wystawionego przez Cricot Mistrza Pathelina.

O braku baśni dramatycznej $\mathrm{w}$ refleksji nad rozwojem polskiego dramatu i teatru w dwudziestoleciu międzywojennym zadecydowało przekonanie, że pojawienie się tych utworów pod koniec XIX wieku było „prostą konsekwencją rozwoju literatury europejskiej, która w wieku XIX w większym niż dawniej zakresie otwarła się na folklor i niewyczerpane zasoby topiki ludowej" 27. Trzeba jednak wyraźnie pokreślić, że twórcy młodopolscy oczywiście sięgali w jakimś stopniu do form folklorystycznych, natomiast były to $\mathrm{w}$ duże mierze utwory zakorzenione $\mathrm{w}$ tradycji form improwizacyjnych, widowiskowych. Młodopolanie w dużym stopniu odwoływali się do konwencji, gatunków stanowiących przeciwwagę dla wzorca dramatu mieszczańskiego.

Nie ulega wątpliwości, że szereg pojawiających się w baśniach dramatycznych rozwiązań to nawiązania do typowo polskich i słowiańskich fabuł, baśniowych postaci i figur. Oczywiste jest jednak, że baśń dramatyczna to „konstrukt stricte literacki, artystowski, ukształtowany na gruncie literatury pisanej i jako taki nieposiadający swego genotypu folklorystycznego" ${ }^{28}$. Konstrukt zanurzony między innymi w tradycji dramy czarodziejskiej, która właściwie przez cały XIX wiek ${ }^{29}$, a szczególnie w jego pierwszej połowie cieszyła się ogromnym powodzeniem ${ }^{30}$, ostatecznie jednak jako forma wyeksploatowana dokonała żywota $w$ teatrach ludowych i amatorskich ${ }^{31}$. Tam

27 R. Waksmund, Młodopolska baśń dramatyczna. Od bajki ludowej do impresji scenicznej (z zagadnien struktury gatunku), s. 13.

28 Tamże, s. 11.

29 Syrena Dniestru, czyli przeróbka niemieckiego Donauweibchen u schyłku lat 30. miała już ponad 40 wystawień, co na warunki ówczesnej produkcji teatralnej w Polsce było wynikiem zdumiewającym. W Warszawie sztuki takie jak Chłop milionowy Raimunda cieszyły się ogromną popularnością, mimo że budziły rozczarowanie krytyków. Podobnie zresztą było w Lwowie [zob. B. Lasocka, Teatr lwowski w latach 1800-1842, Warszawa 1967, s. 117]. Ciekawych danych dostarcza również praca Anny Wypych-Gawrońskiej, Lwowski teatr operowy i operetkowy w latach 1872-1918, Kraków 1999.

30 E. Nowicka, Omamienie - cudowność - afekt. Dramat w kręgu dziewiętnastowiecznych wyobrażeń i pojęć, s. 34 .

31 Trzeba jednocześnie zaznaczyć, że drama czarodziejska powróciła na scenę w latach 90. XIX wieku. Na scenie krakowskiej w 1889 roku wystawiony zostaje Chłop milionowy, w 1900 i 1901 roku natomiast Marnotrawca Raimunda. W tym samym wręcz momencie powstają baśnie dramatyczne. 
najprawdopodobniej „odkryli ją" polscy dramaturdzy poszukujący „teatru ludowego" ${ }^{32}$, który przecież w Polsce wtedy jeszcze nie istniał ${ }^{33}$. To twórcy tacy jak Jerzy Żuławski (Eros i Psyche), Lucjan Rydel (jeden z twórców "teatru ludowego" ${ }^{34}$ ) i Bolesław Leśmian sprawili, że forma ta odżyła raz jeszcze. Jej siła, która pozwoliła tego typu utworom naprawdę długo opierać się rosnącej popularności pièce bien faite, komedii mieszczańskiej, jak i dramatu historycznego, kryła się nie tylko w "cudowności", ,omamieniu", ale i wyjątkowo przejrzystych, schematycznych, a przy tym dających dużo możliwości improwizacyjnych konwencjach.

Nadużyciem byłoby stwierdzenie, że drama czarodziejska była dla polskich twórców formą analogiczną w swojej funkcji do komedii dell'arte we Włoszech albo też bałaganu w Rosji. Trudno bowiem mówić o typowym rodzimym teatrze ludowym, na podstawach którego wyrosnąć mogłaby baśń dramatyczna. Sama baśń była zaś nieco mniej wyrazistą formą od eksperymentów Petito czy Błoka. Trzeba natomiast zwrócić uwagę, że jej pojawienie się w Młodej Polsce było wyrazem pierwszych prób poszukiwania nowych dróg dla polskiego dramatu. Sięgano więc do archiwum form obumarłych i porzuconych na poboczu głównych traktów sztuki i estetyki. O ile formę tę niejednokrotnie wypełniano fabułami zaczerpniętymi z polskiej tradycji ludowej, o tyle sama dramatyczno-teatralna struktura wyłaniała się w wyniku swoistej dla tamtego okresu stylizacji łączącej wybrane formy folklorystyczne, misteryjne, dramę czarodziejską i komedię dell'arte. W ten sposób doszło do zadziwiającego połączenia fabuł zaczerpniętych z ludowych baśni lub mitów $\mathrm{z}$ formą widowiskową, $\mathrm{w}$ pewnym sensie improwizacyjną i wodewilową. Można bowiem podejrzewać, że spora część baśni dramatycznych to rodzaj stylizacji w obszarze konstrukcji świata przedstawionego ${ }^{35}$ nawiązującej zarówno do określonych form tak sztuki ludowej, jak i widowiskowej dramy czarodziejskiej. Formy konceptualizacji przestrzeni dramatycznej to z jednej

32 Sztuki Nestroya i Räedera, ich polskie przeróbki i imitacje trafiają do teatrów amatorskich i ludowych, gdzie obecność tych dzieł jest notowana aż po dwudziestolecie międzywojenne. Zob. A. Chętnik, Dla teatrów amatorskich przegląd 125 sztuk teatralnych, Warszawa 1926; M. Wosiek, Historia teatrów ludowych. Polskie zespoly zawodowe 1898-1914, Wrocław 1975; M. Piotrowska, Lubownicy sceny, czyli polskie teatry amatorskie w Wielkopolsce (1832-1875), Poznań-Kalisz 2000.

33 Zob. Teatry dla masowej publiczności, red. P. Olkusz, M. Wąsik, Łódź 2017.

34 A. Kowalska, Lucjan Rydel i teatr, „Annales Universitatis Paedagogicae Cracoviensis. Studia Historicolitteraria" 2019, nr 19.

35 Na fundamentalne znaczenie tego typu stylizacji w postrzeganiu procesów historycznoliterackich zwracała uwagę Stefania Skwarczyńska. Zob. S. Skwarczyńska, Stylizacja i jej miejsce $w$ nauce o literaturze, w: Stylistyka polska, red. E. Miodońska-Books, A. Kulawik, M. Tatara, Warszawa 1973. 
strony zapis sposobu widzenia pewnej tradycji i wzorców myślenia w niej zakodowanych, z drugiej - to przestrzeń oglądania tych wzorców ubrana w formę improwizacji, „nażywności”, gry i - mówiąc językiem współczesnej teatrologii - performansu.

Trudno oczywiście uznać, że polskie baśnie dramatyczne pełnią w linii rozwoju polskiego dramatu porównywalną funkcję do eksperymentów Błoka, Jewreinowa, Wachtanowa, de Fillippo czy Pirandella. Natomiast można już dostrzec pewne pokrewieństwo między tym, jaką rolę odegrała komedia dell'arte $\mathrm{w}$ połowie XIX wieku dla rozwoju dramatu włoskiego a miejscem, jakie w polskiej literaturze zajęła baśń dramatyczna. Problem jednak w tym, że o ile Włosi bardzo uważnie przyjrzeli się twórczości dialektalnej poprzedzającej wielką metateatralną formę utworów Pirandella, o tyle nad polskimi badaniami nad baśnią dramatyczną nadal ciąży przekonanie o tym, że ta literatura drugiego a nawet trzeciego rzędu nie odegrała żadnej większej roli w rozwoju dramatu. Nie chodzi jednak o to, by na siłę dowartościowywać te utwory, przypisywać im nowatorstwo, którego w nich nie ma albo pojawia się w niewielkim stopniu (oprócz wyjątków takich jak Skrzypek opętany Bolesława Leśmiana). Warto jednak spojrzeć na baśń dramatyczną jako konieczny element rozwoju polskiego dramatu. Formę, która mimo silnej konwencjonalności stanowiła próbę poszukania nowego języka i sposobu mówienia o rzeczywistości, a przede wszystkim była sposobem dotarcia do prawdy o świecie. Dzieła Niemojewskiego, Sarneckiego, Rydla, Oppmana i wielu innych wydają się jednak efektem specyficznego dla okresu przełomu XIX i XX wieku poszukiwania formy odnowienia tradycji teatralnej, przełamania dominującego $\mathrm{w}$ teatrze modelu dramatu mieszczańskiego i piece bien faite, który z dzisiejszej perspektywy razi z pewnością schematycznością i konwencjonalnością. W momencie pisania i wystawiania tych dzieł to właśnie one stanowiły o ogromnej sile tych utworów. Wystarczy choćby przypomnieć, jak dużą popularnością cieszył się Eros i Psyche Jerzego Żuławskiego i opera Ludomira Różyckiego powstała na podstawie tego utworu. Siła afektu tkwiąca w konwencjach, z jakich całymi garściami czerpała baśń dramatyczna ${ }^{36}$, stanowiła nie tylko o popularności tych utworów wśród publiczności mieszczańskiej początków XX wieku. Siła ta okazała się również niezwykle inspirująca dla twórców dwudziestolecia, którzy czerpiąc z owego

\footnotetext{
${ }^{36}$ Jak udowadniają badania Moniki Surmy-Gawłowskiej, również sama komedia dell'arte w Polsce występowała w ograniczonym zakresie, choć warto wspomnieć o obecności trup włoskich na dworze Władysława IV, Jana III Sobieskiego, a także o oświeceniowych utworach Franciszka Bohomolca (Arlekin na świat urażony) i Franciszka Zabłockiego (Arlekin Mahomet). Zob. M. Surma-Gawłowska, Komedia dell'arte, Warszawa 2015, s. 71-78; B. Korzeniewski, Komedia dell'arte w Warszawie, "Pamiętnik Teatralny” 1954, nr 3/4.
} 
misteryjno-baśniowego repozytorium form, modeli i sposobów przedstawienia rzeczywistości, wywracali świat przedstawiony na opak, jeszcze silniej oddziałując na czytelników i widzów.

Wątpliwości nie ulega natomiast, że koniec XIX wieku to czas gwałtownego przyrostu nowych idei i propozycji światopoglądowych, które swój wyraz znalazły w dużej mierze właśnie w tekstach dramatycznych. Te ostatnie funkcjonowały więc zarazem jako środek przekazu wyrazistych idei i koncepcji czy programów, jak i medium treści dopiero kiełkujących, nieostrych, ulotnych. Można oczywiście korzystanie z tradycji baśni dramatycznej traktować jak ariergardę, można jednak dostrzec siłę, jaka tkwi w tym skansenie tradycyjnych obrazów świata i związanej z nimi estetyce. Warto więc być może docenić to kolejne (zapomniane) źródło przemian artystycznych polskiej (często nie mniej zapomnianej) dramatyczno-teatralnej awangardy. Aby uświadomić sobie, jak ważne mogłoby być dla polskiej tradycji szopki i kabaretu, dramatu Mrożka i Różewicza docenienie baśni dramatycznej, wystarczy zestawić ze sobą Betlejem polskie Lucjana Rydla, Ecce homo Ewy Szelburg-Zarębiny, Jasełka moderne Ireneusza Iredyńskiego i Biwak pod gołym niebem Mariana Pankowskiego.

Baśń dramatyczna - niejednoznaczna forma dramatyczno-teatralna czerpiąca z komedii dell'arte, dramy czarodziejskiej, wodewilu czy impromptu funkcjonowała jako swoisty, afektywny „wehikuł treści” łączący aktualne tendencje estetyczne ze zjawiskami nieoczywistymi, często niezrozumiałymi, a jednak zapowiadającymi w pewien sposób możliwości tkwiące w formie dramatycznej. Z możliwości tych skorzystali najwięksi reformatorzy dramatu i teatru.

\section{Bibliografia}

Angelini Franca (2003), Rasoi. Teatri napoletani del '900, Roma: Bulzoni.

Bal Ewa (2007), Lokalność i mobilność kulturowa teatru. Śladami Arlekina i Pulcinelli, Kraków: Wydawnictwo Uniwersytetu Jagiellońskiego.

Barsotti Anna (2007), Eduardo, Fo e l'attore-autre del Novecento, Roma: Bulzoni.

Braidotti Rosi (2018), Afirmation, Pain and Empowerment, „Asian Journal of Women Studies", Vol. 14, No 3, s. 7-36.

Briusow Walery (1993), Niepotrzebna prawda, przeł. B. Stempczyńska, w: O dramacie. Od Hugo do Witkiewicza, red. E. Udalska, Warszawa: Fundacja Astronomii Polskiej, s. 414-418.

Chętnik Adam (1926), Dla teatrów amatorskich przegląd 125 sztuk teatralnych, Warszawa:

Księgarnia Polska. 
Clayton John Douglas (1993), Pierrot in Petrograd. The Commedia dell'Arte/Balagan in Twentieth-Century Russian Theatre and Drama, Montreal-Kingstion-London-Buffalo: Cambridge University Press.

Czabanowska-Wróbel Anna (1996), Baśń w literaturze Młodej Polski, Kraków: Universitas.

Czerska Katarzyna (2019), Teatr Cricot - suma przybliżeń, „Didaskalia”, nr 153, s. 46-54.

Dorak-Wojakowska Lilianna (2019), Dramaturg jako archiwista. O stylu montażu dokumentalnego Witolda Wandurskiego i sceny robotniczej, „Annales Universitatis Paedagogicae Cracoviensis. Studia de Cultura", nr 2, s. 20-35.

Gmys Marcin (2012), „Eros i Psyche”: od powieści scenicznej Jerzego Żuławskiego do opery Ludomira Różyckiego, Poznań: Poznańskie Towarzystwo Przyjaciół Nauk.

Got Jerzy, Orzechowski Emil (1974), Repertuar teatru krakowskiego 1845-1865. Cz. 1: Teatr polski, Warszawa: Instytut Sztuki PAN.

Gracla Jadwiga (2001), Dramaturgia rosyjska przełomu XIX $i$ XX wieku w świetle przemian teatru w Europie, Katowice: Wydawnictwo Uniwersytetu Śląskiego.

Grot Zdzisław (1950), Dzieje sceny polskiej w Poznaniu 1782-1869, Poznań: Nakładem Prezydium Miejskiej Rady Narodowej.

Kelly Catriona (2006), Petrushka: The Russian Carnival Puppet Theatre, Cambridge: Cambridge University Press.

Korzeniewski Bohdan (1954), Komedia dell'arte w Warszawie, „Pamiętnik Teatralny”, nr 3-4, s. 29-56.

Kosofsky Sedgwick Eve (2003), Touching Feeling. Affect, Pedagogy, Performativity, Durham - London: Duke University Press Books.

Kotow Helena (1982), Tradycje teatru ludowo-jarmarcznego w dramacie Fiodora Sołoguba „Wańka klucznik i jego paź Jean”, "Zeszyty Naukowe Wydziału Humanistycznego Uniwersytetu Gdańskiego. Filologia Rosyjska", t. 10, s. 31-41.

Kowalska Agnieszka (2019), Lucjan Rydel i teatr, „Annales Universitatis Paedagogicae Cracoviensis. Studia Historicolitteraria", nr 19, s. 21-34.

Lasocka Barbara (1967), Teatr lwowski w latach 1800-1842, Warszawa: Państwowy Instytut Wydawniczy.

Lo Gatto Ettore (1954), La Commedia dell'arte in Russia. „Rivista di studi teatrali”, nr 9-10, s. 176-186.

Madej Izabella (2002), Syndrom budy jarmarcznej, czyli symbolizm rosyjski w kregu arlekinady, Wrocław: Wydawnictwo Uniwersytetu Wrocławskiego.

Marszałek Agnieszka (1992), Repertuar teatru polskiego we Lwowie 1875-1881, Kraków: Instytut Sztuki PAN.

Massumi Brian (2013), Autonomia afektu, przeł. A. Lipszyc, „Teksty Drugie” , nr 6, s. $112-135$.

Mazur-Fedak Jolanta (2008), Józef Jarema w międzywojennym teatrze awangardowym Cricot (I), Kraków: Universitas.

Nicoll Allardyce (1967), W świecie Arlekina. Studium o komedii dell'arte, przeł. A. Dębnicki, Warszawa: Państwowy Instytut Wydawniczy.

Nowicka Elżbieta (2003), Omamienie - cudowność - afekt. Dramat w kręgu dziewiętnastowiecznych wyobrażeń i pojęć, Poznań: Wydawnictwo Naukowe UAM. 
Olkusz Piotr, Wąsik Monika [red.] (2017), Teatry dla masowej publiczności, Łódź: Wydawnictwo Przypis.

Osińska Katarzyna (2013), Metamorfozy „Budy jarmarcznej”: Aleksandr Błok - Wsiełowod Meyerhold - Tadeusz Kantor, „Prace Filologiczne. Literaturoznawstwo”, nr 6, s. $103-114$.

Piotrowska Magdalena (2000), Lubownicy sceny, czyli polskie teatry amatorskie w Wielkopolsce (1832-1875), Poznan-Kalisz: Wydawnictwo Naukowe UAM.

Połczyńska Edyta, Załubska Cecylia (1995), Bibliografia przekładów z literatury niemieckiej na język polski 1800-1990, t. 1: 1800-1918, Poznań: Wydawnictwo Naukowe UAM.

Roach Joseph (2014), Wprowadzenie: historia, pamięć i performans, przeł. M. Borowski, M. Sugiera, „Didaskalia”, nr 121-122, s. 22-36.

Rzewuska Elżbieta (1988), Polski dramat ekspresjonistyczny wobec konwencji gatunkowych, Lublin: Uniwersytet Marii Skłodowskiej-Curie.

Rzewuska Elżbieta (1991), Misterium i moralitet w polskim dramacie międzywojennym, w: Dramat $i$ teatr religijny w Polsce, red. I. Sławińska, W. Kaczmarek, Lublin: TN KUL, s. 287-328.

Schneider Rebecca (2011), Performing Remains. Art and War in Times of Theatrical Reenactment, London-New York: Routledge.

Secomska Henryka (1971), Repertuar warszawskich teatrów rządowych 1863-1890, Warszawa: Instytut Sztuki PAN.

Skwarczyńska Stefania (1973), Stylizacja i jej miejsce w nauce o literaturze, w: Stylistyka polska, red. E. Miodońska-Books, A. Kulawik, M. Tatara, Warszawa: Państwowe Wydawnictwo Naukowe, s. 227-248.

Sobieska Anna (2015), Wokót Aleksandra Błoka. Z dziejów polskiej fascynacji kultura i literatura rosyjska, Warszawa: Fundacja Akademia Humanistyczna.

Stoller Ann Lauea (2002), Colonial archives and the arts of governance, „Archival Science”, No 2, s. 87-109.

Sugiera Małgorzata (2017), Nażywość, w: Performatyka. Terytoria, red. E. Bal, D. Kosiński, Kraków: Wydawnictwo Uniwersytetu Jagiellońskiego.

Surma-Gawłowska Małgorzata (2015), Komedia dell'arte, Kraków: Universitas.

Świetlicka Halina (1968), Repertuar teatrów w Warszawie 1832-1862, Warszawa: Instytut Sztuki PAN.

Taylor Diana (2003), The Archive and the Repertoire, Durham-London: Duke University Press Books.

Taylor Diana (2014), Archiwum i repertuar: performanse i performatywność. PerFORwhat studies?, przeł. M. Borowski, M. Sugiera, „Didaskalia”, nr 120, s. 22-38.

Waksmund Ryszard (2005), Młodopolska baśn dramatyczna. Od bajki ludowej do impresji scenicznej (z zagadnień struktury gatunku), w: Baśnie nasze współczesne, red. J. Ługowska, Wrocław: Uniwersytet Wrocławski, s. 11-41.

Wosiek Maria (1975), Historia teatrów ludowych. Polskie zespoły zawodowe 1898-1914, Wrocław: Instytut Sztuki PAN.

Wypych-Gawrońska Anna (1999), Lwowski teatr operowy i operetkowy w latach 1872-1918, Kraków: Universitas. 


\title{
Affect and Convention: Creating the Space of Seeing
}

\begin{abstract}
The article discusses the coexistence of two phenomena in the drama of the second half of the $19^{\text {th }}$ century and the early $20^{\text {th }}$ century. By combining affect and convention, the author seeks to point out the dramatic use of the forgotten plot schemes, characters, and construction solutions, which still remain strongly preserved in the cultural memory of the viewers. These were highly characteristic of the comedy dell'arte, the Russian balagan, which was at the time regaining its popularity in Italy, as well as of the Polish fairy tale. The authors used them in order to evoke in the viewer a certain kind of affectation. This, in turn, allowed them to build ties with the audience based on completely new rules of participation, which gave rise to the theatrical phenomena characteristic of the second half of the $20^{\text {th }}$ century.
\end{abstract}

Keywords: drama, comedy dell'arte, affect, convention, space 